\title{
Colchicine-Site Binding Agent
}

National Cancer Institute

\section{Source}

National Cancer Institute. Colchicine-Site Binding Agent. NCI Thesaurus. Code C67421.

An anti-mitotic compound that binds to the beta tubulin subunit at the $\mathrm{N}$-terminal domain (within residues 1-41) and within residues 214-241. Agents binding at the colchicine site produce a conformational change in the protofilament structure which subsequently impairs the polymerization of tubulin dimers and thereby prevents the formation of microtubules. The subsequent decrease in the amount of formed microtubules causes disassembly of the mitotic spindle resulting from instability of the structure during the mitotic interphase, leading to cell cycle arrest and/or apoptosis. 